\title{
監素化 反應に依る潤滑油の製造
}

\author{
小林 良之助
}

1. 航空潤滑油成分。

航空潤滑油としては，パラフィン炭化水素を主 成分と导るパラフィン基性油が最適なりと考察せ
られたることあるも，潤滑油溜分中のパラフィン 炭化水素は，主として高融點にして且つ低粘度の 石䗵分なり。この石蠟分は，一般に適當なる方法 に依て潤滑油溜分より分離せらる。斯くて航空潤

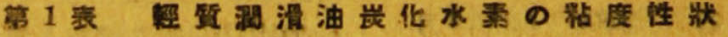

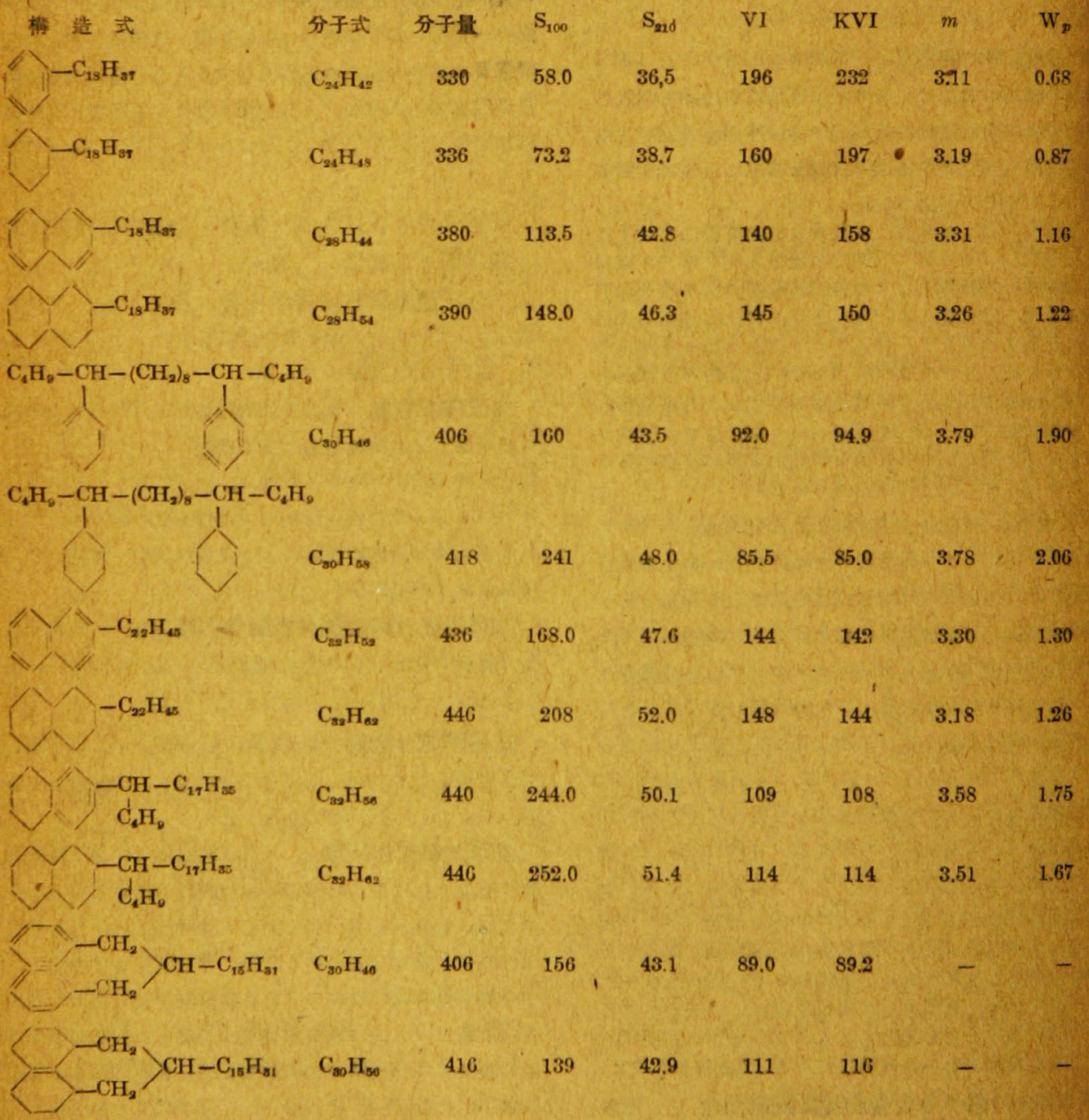


滑油の主成分炭化水素は，1 分子內に 1 3 個の 芳香族環又はナフテン環を有し，之に長きパラフ; ン側鎻の結合せるアルキル環狀炭化水素, 特にア ルキルナフテン炭化水素なり。斯る炭化水素は一 般に高粘度指數度り。

粘度指數の最高標準油なるペンシルパニア產原 油D潤滑油 る, 筫驗式が $\mathrm{C}_{n} \mathrm{H}_{2 n-4} \sim \mathrm{C}_{2 n} \mathrm{H}_{2 n-8} \ll \mathrm{L}$ て, 1 分子內に數個のペンゾール環又はナフテン 環の存在するととが推定せらる。之れ代表的パラ フ、ン基性油なり。混合基性油, ナフテン基性油 となるにつれて, 1 分子內に順次多数の芳香族環 及びナフテン環を有し，(成環炭素數：側鋇炭素 數) 比が漸增す。然れどす, 粘度の溫度變化は此 の比に依てのみ決定するものにすらす，高粘度指 數の潤滑油は, 分子全體の形が長顉狀をなし，山 咬之助氏の所謂分子絡合長形度が大なるてとを 要す。

アルキル環狀炭化水素は，低溫て於て對應する バラフィン炭化水素よりも熱安定度小应るも，そ ○分解が生起する如き高溫に於ては，パラフィン 炭化水素よりる熱安定度大なり。然れどる,アル キル側鑽の不飽和度が堽大する際には安定度が低 下して，熱重合の傾向を增大す。

又，相對應するアルキル芳香族とアルキルナフ テンとにては、アルキル芳香族はアンチノっク性に して,燃燒室內に漏入してもガリリンのアンチノ。

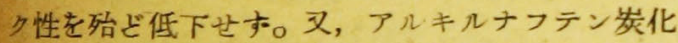
水素は對應するアルキル芳香族炭化水素よりも， 粘度及び粘度指數が僅かに高きてと，第 1 表の如 Lo

第 1 表に於て, $\mathrm{S}_{100}$ は $100^{\circ} \mathrm{F}$ て於けるセイポ ルト粘度(S.U.S.)， $S_{9 \text {. }}$ は $210^{\circ} \mathrm{F}$ と於ける゙セイ ボルト粘度，VI は粘度指數，KVIは動粘度指 數， $m$ は傾斜揸數，W，は粘度標高を示す。

斯くて, 1 分子內に $1 \sim 3$ 個の環を有する長鋇 狀のアルキルナフテン又はアルキル芳香族炭化水 素は，とも几航空滑滑油として理想的成分なるも 詳細に檢討する時は各及長短を認め得へし。

2. 高級潤滑油としてのナフテン炭化 水素
潤滑油溜分(鑟油)上り溶劑抽出に依て得たるパ ラフィン基性潤滑油の主成分が，長鎻狀のアルキ 几基に 1〜3 個のナフテン核又はペンゾール核の 結合せる長鎖狀アルキル環狀炭化水素, 特に長鎻 狀アルキルナフテン炭化水素なることは, 多數の 報告あり。

パラフィン基性潤滑油の合成は, 斯る長鎻狀ア ルキル環狀炭化水素の生成を目的として行はる。 その代表的なる方法は次の如し。

（1）各種分解溜分，頁岩油溜分，コガジン等， オレフィン炭化水素含油分の直接重合法

(2) アルコールの脫水重合, 監素化パラフィン ○脫監素重合等, 中間體として不飽和炭化水素を 生成する間接重合法

（3）芳香族及びナフテン炭化水素の接觸的アル キル化, 監素化パラフィンと芳香族炭化水素の接 触的縮合等，アルキル芳香族及びアルキルナフテ ン炭化水素の直接生成等なり。

今日，高級潤滑油の製造を目的として工業的に 遂行せらるる溶劑抽出法及び合成法等は，凡て長 鑍狀丁儿キル環狀炭化水素を製造する方法なり。 その二三を例示す。

(1) コガジンを原料とする合成潤滑油……此の 合成潤滑油は，オレフィン炭化水素の $\mathrm{AlCl}_{3}$ 重合 に依て生成せる潤滑油として代表的なるものにし て, 平均分子 $1 モ$ 几當り約 1 個のエレチン結鏆を 有す。此のエチレン結鏳は，䢱元二っケ几 $20 \%$ を 触媒として, 初厴 $80 \mathrm{~kg} / \mathrm{cm}^{2}$, 溫度 $250^{\circ} \mathrm{C}$ に於て 3〜4時間水素添加する時注, 完全に飽和するとと を得。第 2 表に水添前後の性狀變化を比較し, 又 水添油の比届折及び平均分子量より環分析法に從 $\tau$, その平均分子權造を比較す。

第 2 表に於て, 合成油の本均分子構造は, 環分 析結果より，合成油を單環アルケンナフテン炭化 水素とし，その水添油を單環アルキルナフテン炭 化水素亡決定せり。此の分子㯕造に基をて原子屈 折より計算せる分子届折は，筫测值之極めてよく 一致す。

故に, $\mathrm{AlCl}_{s}$ を觸媒として, オレフィン炭化水 素を重合して生成せる合成潤滑油の平均成分は, 長鎻狀アルケンナフテン炭化水素にして，その水 
第 2 表合成閵滑油の水添油性狀

沃素幅 $(g-I, / g-モ ル$ 油)

比 重 $d_{20}^{20}$

平均分子最

鲃粘 度 $\operatorname{cst}\left\{\begin{array}{l}20^{\circ} \mathrm{C} \\ 50^{\circ} \mathrm{C}\end{array}\right.$

粘度標高 $\mathrm{W}_{p}$

ア リン 䛸 ${ }^{\circ} \mathrm{C}$

属折幽 $n_{\mathrm{D}}^{20}$

1) ラクテビテ

インターセブト, $\mathrm{R}^{20}$

比屈折

合堆油

水添油

合成油 II 水添油 I

283
0.848

0.846

276

-

合成油 III

水添油 III

850

852

0.842

345

1642

1755

543

562

0.844

0.841

473

516

521

207.4

211.8

73.8

499

585

593

2.01

2.10

73.1

72.8

73.5

$138.9 \quad 142,0$

2.23

2.39

3.10

3.16

$1.4711 \quad 1.4693$

124.1

127.6

116.5

123.4

$1.047 \quad 1.046$

.4685

1.4695

1.4660

- 0.3294

1.048

1.046

$1.04 \mathrm{C}$

1.045

1.3297
$-\quad 0.36$

0.95

3293

ナフテン㩆数/モル

惯躍式

分子式

$\mathrm{C}_{n} \mathrm{H}_{2 n-2} \quad \mathrm{C}_{n} \mathrm{H}_{2 n}$

$\mathrm{C}_{n} \mathrm{H}_{2 n-2} \quad \mathrm{C}_{n} \mathrm{H}_{-n}$

$\mathrm{C}_{n} \mathrm{H}_{2 n}$

1.05

$\mathrm{C}_{80.8} \mathrm{H}_{119} \quad \mathrm{C}_{63.8} \mathrm{H}_{121}$

$\mathrm{C}_{38.0} \mathrm{H}_{75.8} \quad \mathrm{C}_{40.1} \mathrm{H}_{8} \times .2$

$\mathrm{C}_{87.0} \mathrm{H}_{71.5} \quad \mathrm{C}_{37.2} \mathrm{H}_{74.3}$

平均分子㩐造

$-\mathrm{C}_{54.5}$
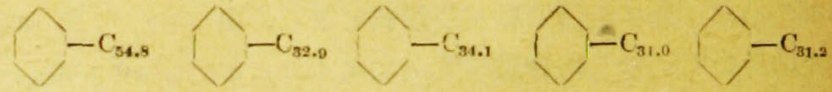

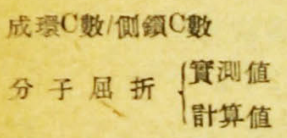

0.109

0.109

0.182

0.175

0.193

0.191

- 281

$-$

185

172

281

186

172

第 3 表セレシン分解溜分の重合溜分

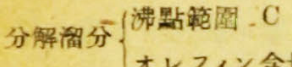

合成润滑油收最 $\%$

渭漟油性狀

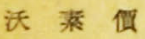

此重 $d_{s}^{20}$

屈折残 $n_{\mathrm{D}}^{20}$

$60 \sim 70$

96

$140 \sim 160$

95

91

79.5

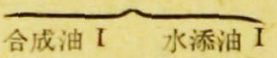

合成油 II 水添油 II

合成油 III 水添油 III

78.9

0.7

71.2

37.2

0.2

$\begin{array}{ll}0.8691 & 0.8657\end{array}$

$1.4812 \quad 1.4777$

0.8721

0.8616

0.8584

1フラクテピテー

インターセプト, $\mathrm{R}^{20}$

政粘度 $\operatorname{cst}\left\{\begin{array}{l}20^{\circ} \mathrm{C} \\ 50^{\circ} \mathrm{C}\end{array}\right.$

粘度標高

動粘度指数

平均分子量

比属折

$\ulcorner=リ ン$ 點 $\mathrm{C}$

嘋固 點 ${ }^{\circ} \mathrm{C}$

ナフテン骤|モれ

エレチン結颃敗/モル

霓 駼 式

分子式

1.047

1.045

1.4872

1.4820

$1963 \quad 2280$

225

2.15

256

85.3

2.10

87.5

748

0,3276

735

127.8

0.3268

133.5

$-30$

$-28$

2.25

2.21

2.31

1.049

1.046

1.4807

1.4768

平均分子藓造

成環C數/侧算

分子屈折 $\begin{cases}\text { 計 } & \text { 算 } \\ \text { 货 } & \text { 测 }\end{cases}$

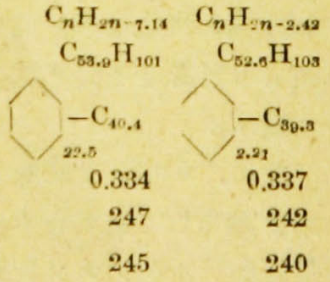

4570

5290

637

1.69 .

110

1103

1116

0.3280

141.5

0.3269

145.8

$-18$

$-17$

2,91

2.88

1.050

1.048

6732

4937

1122

809

1.31

1.33

123

122

1969

1746

0.3301 -

0.3290

164.7

109.

$-22$

$-20$

3.13

1.69

1,51

$\mathrm{C}_{n} \mathrm{H}_{2 n-10.8} \quad \mathrm{C}_{n} \mathrm{H}_{2 n-3.70}$

0

$\mathrm{C}_{80.4} \mathrm{H}_{150} \quad \mathrm{C}_{70.0} \mathrm{H}_{154}$

$\mathrm{C}_{141} \mathrm{H}_{275}$

$\mathrm{C}_{n} \mathrm{H}_{2 n+1.02}$

$\mathrm{C}_{2.01}-\mathrm{C}_{\mathrm{e2.8}}$

0.277

( $-\mathrm{C}_{61.7}$

367

0.280

$-\mathrm{C}_{131}$

1.69
0.077

$\mathrm{C}_{125} \mathrm{H}_{249}$

366

362

651

$\int_{1.53}^{-C_{110}}$

0.078

579

650

574 
添油は長鑍狀アルキルナフテン炭化水素なり。之 等はともにパラフィン基性油の主成分をなす。又, 今日工業的に行はるる油脂, 脂肪酸, アルコール, 頁岩油，石蠟熱分解油等を原料としての合成潤滑 油の主成分は，凡てアルケンナフテン又はフルキ ルナフテン炭化水素なり。

（2）石蛆の熱分解オレフィンを原料とする合成 㵎滑油……第 3 表に合成セレシンの熱分解溜分の 低沸點分と高沸點分亡より得たる合成潣滑油，及 びその水添油の平均分子槥造を示す。

聯に, 分子届折の計算値は, 分子檴造に基きて 原子屈折より計算せるるのにして, 實测值之極内 てよく一致す。郎ち，石蠟の氣相熱分解溜分（高 次オレフィン）を接觸重合して得らるる合成潤滑 油は, 長䥊狀アルケンナフテン炭化水素にして, 1 分子內に 1.5 3.0 個のナフテン環を有する 多, その（成環 C數：側鎻 C 數）比は. $0.07 \sim 0.35$ の 範園にありて，全䐺として長鋹狀をなし，理想的 パラフィン基性油をなするのなり。

\section{3. 鹽素化石蠟の脫鹽素重合油}

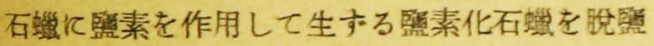
素重合する際にも，パラフィン基性の高級閵滑油 を合成することを得。眖覽素重合には，活性白土 $\mathrm{AlCl}_{3}, \mathrm{ZnCl}_{2}$ 又はその混合體を触媒として, $250^{\circ} \mathrm{C}$ 附近に加熱す。此の合成油の水添精製油及び溶剂 抽出の精製油は，何れる長顉狀アルキルナフテン 芳香族（アルキル水素化芳香族）を主成分とす。 その性狀の一例を示ナに, 比重, $d_{4}^{25}, 0.9235$, 屈折率, $n_{\mathrm{D}}^{25}, 1.5302$, リフラクテビテー インター セプト, $R^{25}, 1.068$, 平均分子量 480 , 臭素價 39.8 エチレン結鎻數 /モれ，0.753，元素組成， C \% , $87.5, \mathrm{H} \%, 12.5$, 計算元素組成, $\mathrm{C} \%, 87.3, \mathrm{H} \%$, 12.7 , 分子式, 實測, $\mathrm{C}_{35.5} \mathrm{H}_{50 \cdot 5}$, 計算, $\mathrm{C}_{38.8} \mathrm{H}_{80.4}$ 實驗式，貝測， $\mathrm{C}_{n} \mathrm{H}_{2 n-10}$, 計算, $\mathrm{C}_{n} \mathrm{H}_{2 n-0 \cdot 511}$, 平 均分子構造(推定), ( 側鎖 C 數）比 0.521 , 分子屆折, 實測, 160 , 計算, 157.3 , 動粘度, cst, $100^{\circ} \mathrm{F}, 320,210^{\circ} \mathrm{F}, 22.4$, 動粘度指數 106 , 粘度比重恒數 0.864 なり.茲に 計算值は, 先づ筫測賽驗式, リフラクテビテー
インターセプト，其他の性狀より之を双環しナフ テン，ペンゾール）環狀炭化水素と推定して，實 驗式を決定し，此の實驗式に基づきて分子式，元 素組成, 平均分子構造の順に決定し, 此の平均分 子構造より（成環 $\mathrm{C}$ 數：側鎻 C 數) 比を決定 $\mathrm{L}$,

又, アイゼンロールの原子用折より分子鳳折を計 算す。その計算值を實測值とは極めてよく一致す る故に, 哥素化石蠟の脫監素重合油は双環水素化 芳香族炭化水素にして，その（成環 C 數：側鎖 C 數) 比は約 0.5 であり, 高粘度指數を示すう郎ち パラフィン基性油に風し，その主成分は溶劑抽出 て於て, 精製油（ラフィネート）上して得らる。 此の方法に依て高級潤滑油を合成するには,

（1）石蠟を覧素化し，(2）次に接触的脫膸素重合 L, (3) 脫監素重合油を低溫厭水素添加 L, (4) 水

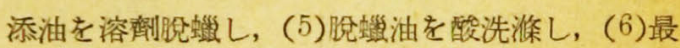
後に溶劑抽出す。工業的には，此の合成過程に於 て，水素添加の過程を省略すると己を得。叉，水 素添加の過程を採用する時は，溶劑處理の過程を 省略す。

第 1 2 圖に石蠟に對する監素添加量の合成油 性狀に及ぼす影響を示し，第 3〜4 圖に監素化石 蠙を脫監素重合する際の觸媒量の合成油性狀に玄 ほす影響を示し，第 $5 \sim 6$ 圖に脫監素重合油を低 溫壓水添する際の水添溫度が水添油性狀に及棌す 影響を，同じく第 7 圖は水添時間が水添油性狀に 及壮す影響を示す。

之等の結果より平均融點 $52^{\circ} \mathrm{C}$ の石蠟を原料と して高級潤滑油を合成する條件を考察するに，次 の如し。

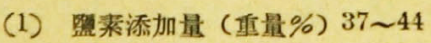

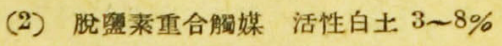

(3) 脱盟素重合罝度 $280^{\circ} \mathrm{C}$

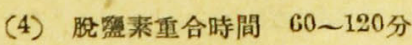

斯る條件下に生成せる合成潤滑油の性狀は,

（1）比重, $d_{4}^{15}, 0.895 \sim 0.920$, (2)引火點 $170 \sim 220^{\circ} \mathrm{C}$ (3) 粘度 $\left(210^{\circ} \mathrm{F}\right.$, S.U.S.) $70 \sim 160$ 秒，(4) 粘度 指数 $95 \sim 120$, (5) 殘留炭素 $1.60 \sim 2.90$, (6) 流 動點 $-5.0 \sim 28.0^{\circ} \mathrm{C}$ なり。 

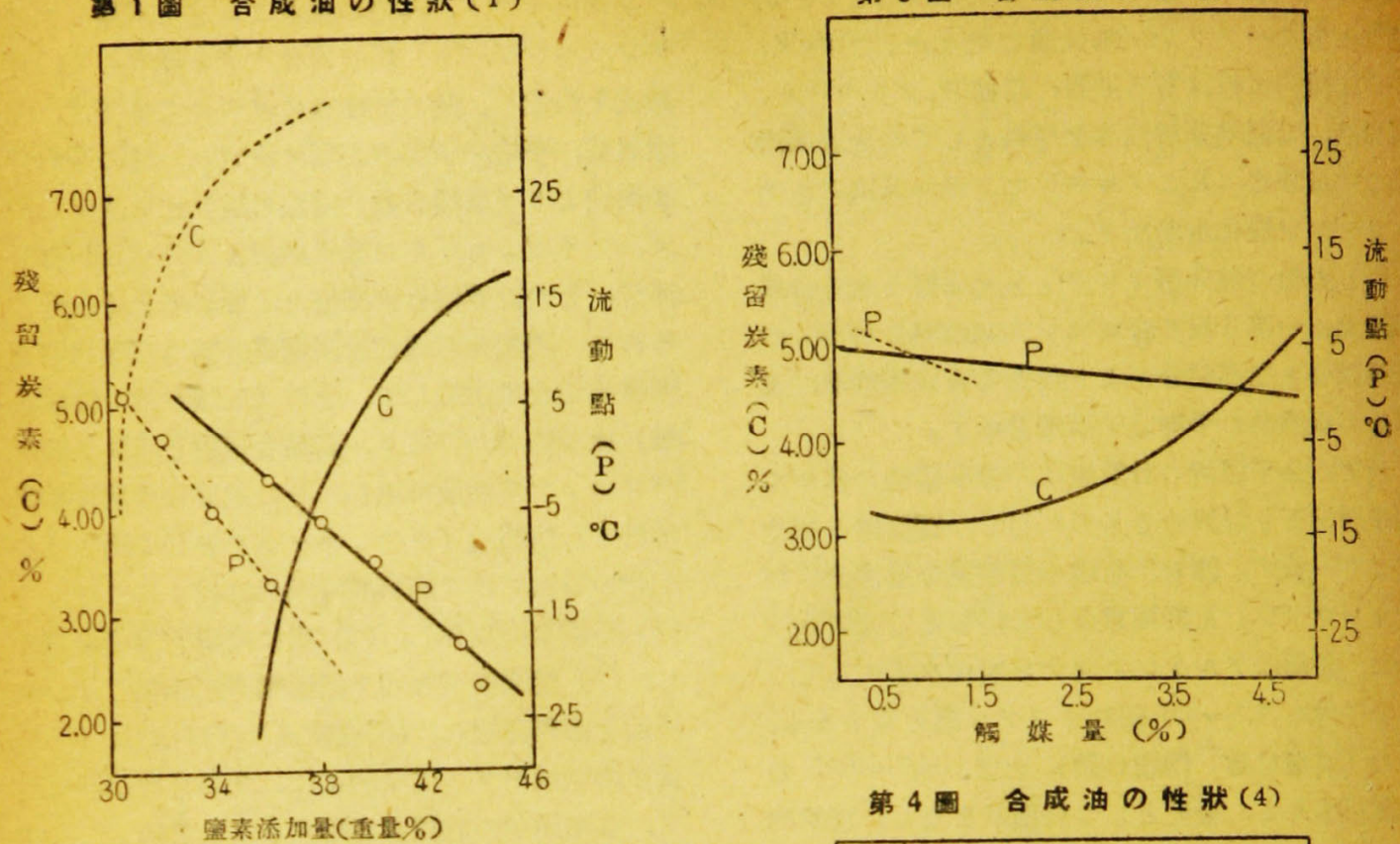

第 4 娄合成油の性狀 (4)

第 2 图合成油の狀 (2)

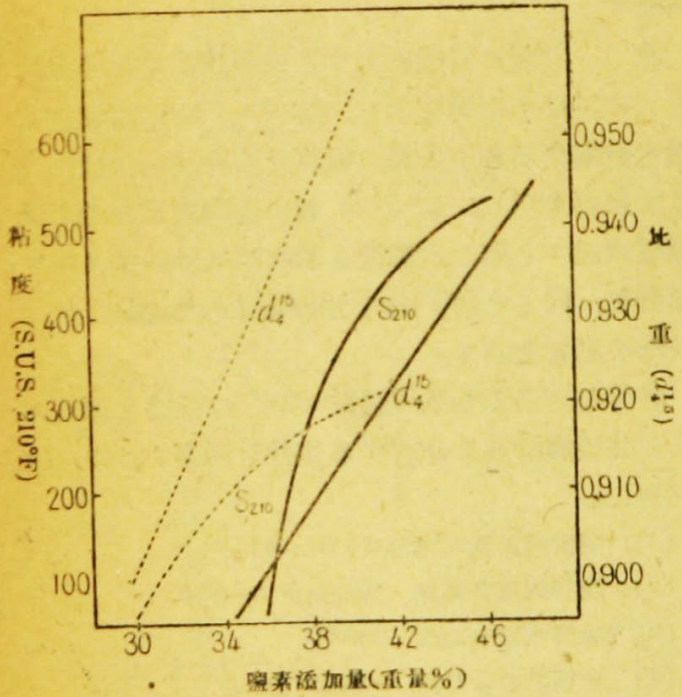

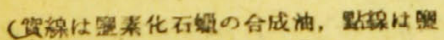
繁化蜺下油の合成讫示子)

4. 縮合潤滑油

監素化石蝩を脫監素重合して得らるる合成油は 高粘度指數なるも, 残留炭素分高く, 安定度に於 て邀色あり。然るに，監素化石鼣をフリーデルク

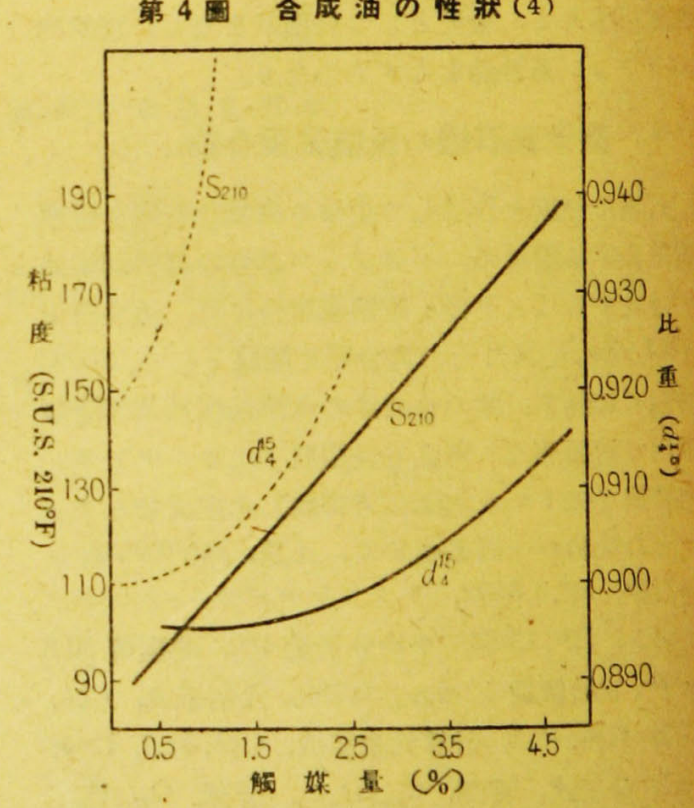

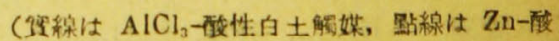
性白土距媒を示す)

ラフト反應に從つて芳香族炭化水素特にベンゾー ルと縮合して生成する縮合潤猾油は，淡黄色油飞 して, 殘留炭素分低く, 安定度高し。縮合の觸媒 には $\mathrm{AlCl}_{3}$ と活性白土の等量混合體を使用す。 此の活性白土の作用は, $\mathrm{AlCl}_{\mathrm{a}}$ の作用を緩和して 
弟 5 圆 水添合成油の性彇 (1)

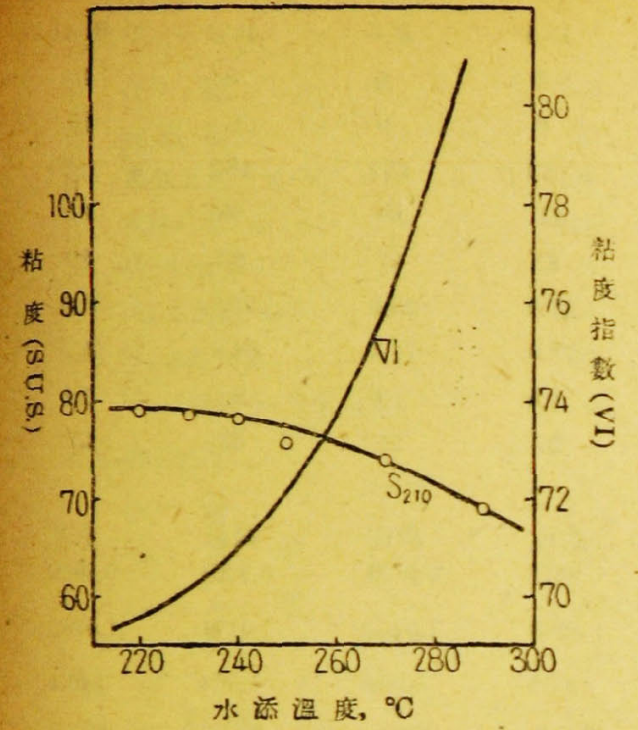

第 6 图水添合成油の继垘 (2)

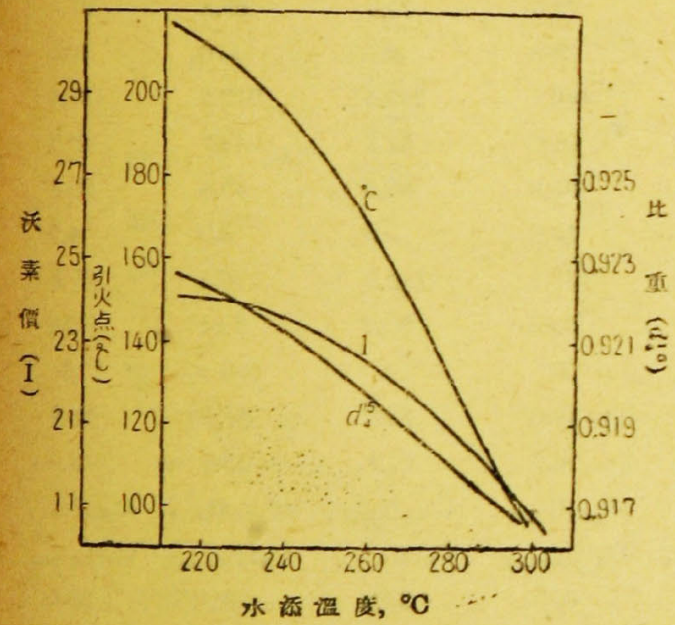

而もその作用生命を趜長するものなり。監素化石

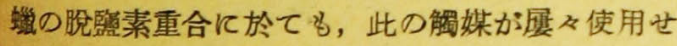
らる。

ベンダールと監素化石䗰の接觛縮合に當つて は; 監素化重合に比較して, 脫監素溫度を約 $100^{\circ} \mathrm{C}$ 降下し得るのみならす,又,觸媒量の增加につれて 解重合が促進し, 生成油の平均分子量, 粘底, 比 重, 殘留炭素分等を減少す。

縮合油の主成分は, 多環式アルキ几芳香族炭化 水素にして, 高粘度指數を示し, 所謂パラフィン 基性に嵹しアアニリン點比較的高し。そを低溫壓
筙 7 水添合成油の性狀 ( 3 )

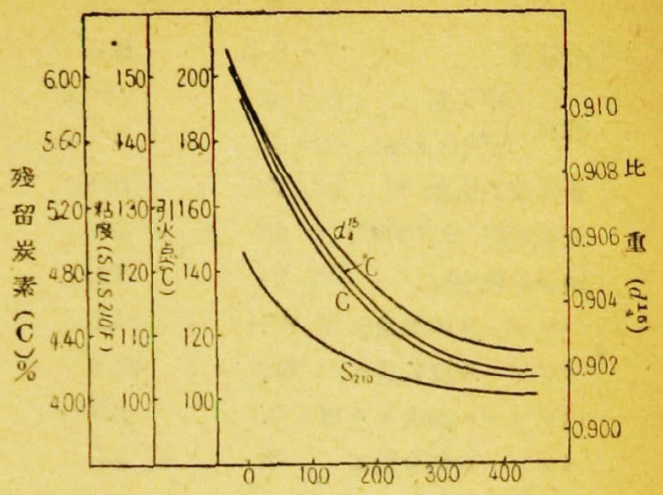

水添時阔, $\min \left(300^{\circ} \mathrm{C}\right)$

第 8 園 パラフィン・テンソール缩合油の性狀

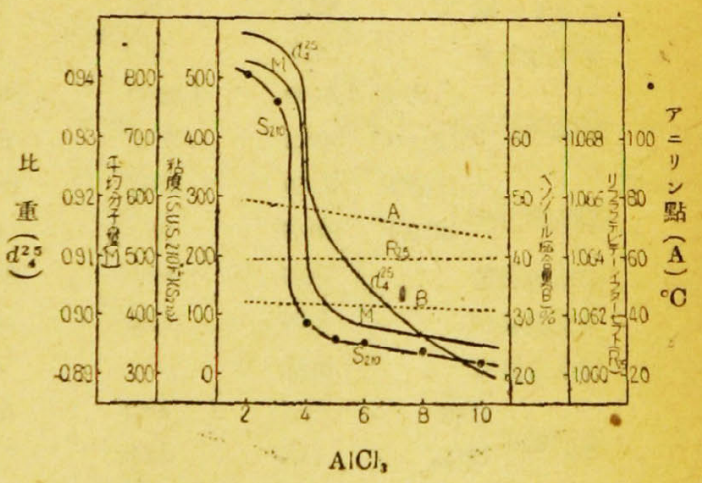

水素添加する際には, 多環式アルキルナフテン炭 化水素に㬚化し，アニリン點上昇するも，粘度及 ひ粘度指数殆ど變化せす。

（1）パラフィ:ン・ベンン゙ール縮合油資料には 融點約 $52^{\circ} \mathrm{C}$ の石䗈に約 40\% 監素添加せるものを 使用す。その比重, $d_{4}^{25}, 1.0286$, 屈折率, $n_{\mathrm{D}}^{25}$, 1.4989, リラクテビテーインターセプト， $\mathrm{R}^{25}$, 0.9846 , 平均分子量 440 , 監素含量 $28.5 \%$ （重量 \%) 凝固點 $0^{\circ} \mathrm{C}$ の淡黄色油なり。此の頤素化石侅 を純ベンン゙ールと接触的に縮合す。

縮合反應には, 先づ $400 \mathrm{~g}$ の゚ンソ゚ールを $\mathrm{AlCl}_{3}$ 
第 4 表 パラフィン・ヘンゾール縮合油の性狀

\begin{tabular}{|c|c|}
\hline \multicolumn{2}{|l|}{ 宿合條件 } \\
\hline 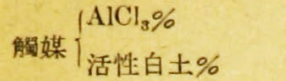 & \\
\hline 最高反然溫度 ${ }^{\circ} \mathrm{C}$ & \\
\hline 反際時間, 分 $\left(180^{\circ} \mathrm{C}\right)$ & \\
\hline 縮合油收率\% & \\
\hline ヘンンンール添加量\% & \\
\hline こンゾール间收量\% & \\
\hline ペンゾール縮合モル比 & \\
\hline ペンゾール縮合量％ & \\
\hline
\end{tabular}

樎合油性狀

\begin{tabular}{|c|c|c|c|c|c|c|c|}
\hline 色 相 & 櫈黄 & 淡谐 & 㷋㛜 & 谈蓝 & 淡萤 & 淡黄 & 淡黄 \\
\hline 比 重 $d_{4}^{2 s}$ & 0.9472 & 0.9463 & 0.9209 & 0.9117 & 0.9051 & 0.9001 & 0.8909 \\
\hline 屈折來 $n_{\mathrm{D}}^{25}$ & 1.5363 & 1.5371 & 1.5248 & 1.5200 & 1.5165 & 1.5141 & 1.5092 \\
\hline $\begin{array}{l}\text { リフラクテピテー } \\
\text { インターセブト, }\end{array}$ & 1.063 & 1.064 & 1.064 & 1.064 & 1.064 & 1.064 & 1.064 \\
\hline 比分散 & 234.8 & 240.6 & 240.9 & 235.4 & 234.1 & 234.3 & 237.3 \\
\hline$Y=リ ン$ 點 ${ }^{\circ} \mathrm{C}$ & 82.2 & 76.9 & 73.5 & 72.0 & 71.5 & 69.8 & 67.1 \\
\hline 平均分子量 & 817 & 805 & 505 & 398 & 388 & 376 & 334 \\
\hline $\int^{100^{\circ} \mathrm{F}}$ & 1.5149 & 1.3269 & 862.1 & 440.3 & 293.5 & 212.2 & 137.4 \\
\hline 粘度 $(\mathrm{S}, \mathrm{U} . \mathrm{S}).\left(210^{\circ} \mathrm{F}\right.$ & 505.2 & 458.2 & 84.5 & 62.0 & 54.1 & 48.7 & 42.3 \\
\hline $\int^{100^{\circ} \mathrm{F}}$ & 3279 & 2872 & 186.6 & 95.3 & 63.5 & 45.6 & 29.2 \\
\hline 動粘度 (cst) $\left.\right|_{210^{\circ} \mathrm{F}}$ & 108.6 & 98.8 & 16.7 & 10.8 & 8.5 & 6.9 & 4.9 \\
\hline 䦽粘度指數 & 98.6 & 99.5 & 102.4 & 105.1 & 112.0 & .116 .5 & 107.8 \\
\hline 残留炭来％ & 0.66 & 0.62 & 0.39 & 0.25 & 0.24 & 0.14 & 0.08 \\
\hline 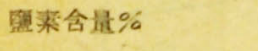 & 痕跡 & 0 & 0 & 0 & 0 & 0 & 0 \\
\hline $\iint_{\%} \mathrm{C}$ & 88.4 & 88,2 & 88.1 & 88.0 & 88.2 & 88.0 & 88.0 \\
\hline 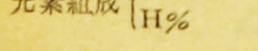 & 11.6 & 11.8 & 11.9 & 12.0 & 11.8 & 12.0 & 12.0 \\
\hline 分子式 & $\mathrm{C}_{60.3} \mathrm{H}_{04.5}$ & $\mathrm{C}_{50.1} \mathrm{H}_{04.0}$ & $\mathrm{C}_{37.1} \mathrm{H}_{80.1}$ & $\mathrm{C}_{20.1} \mathrm{H}_{47.7}$ & $\mathrm{C}_{2 \times .5} \mathrm{H}_{47.3}$ & $\mathrm{C}_{27.5} \mathrm{H}_{45.1}$ & $\mathrm{C}_{24,4} \mathrm{H}_{40,0}$ \\
\hline 實蹹式 & $\mathrm{C}_{n} \mathrm{H}_{2 n-25.0}$ & $\mathrm{C}_{n} \mathrm{H}_{2 n-2 \mathrm{a.3}}$ & $\mathrm{C}_{n} \mathrm{H}_{2 n-14.2}$ & $\mathrm{C}_{n} \mathrm{H}_{y n-10.5}$ & $\mathrm{C}_{n} \mathrm{H}_{2 n-0.7}$ & $\mathrm{C}_{n} \mathrm{H}_{2 n-9 \cdot 9}$ & $\mathrm{C}_{n} \mathrm{H}_{2 n-s, s}$ \\
\hline 沃 素 㗄 & 32.0 & 30.8 & 29.6 & 30.1 & 28.0 & 34.1 & 29.0 \\
\hline $\begin{array}{l}\text { エチレン結鋇数/モ } \\
\text { 環分析 }\end{array}$ & $=2 \quad 1.0$ & 1.0 & 0.6 & 0.5 & 0.4 & 0.5 & 0.4 \\
\hline 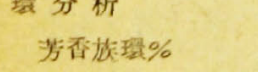 & 34 & 33 & 31 & 27 & 28 & 33 & 31 \\
\hline ナフテン環％ & 0 & 0 & 0 & 0 & 0 & 0 & 0 \\
\hline パラフィン側鍕\% & 66 & 67 & $69^{\circ}$ & 73 & 72 & 67 & 69 \\
\hline 1分于內環數 & 3.5 & 3.3 & 2.0 & 1.4 & 1.4 & 1.6 & 1.3 \\
\hline 成環 C數／侧鋤 C數 & 0.53 & 0.50 & 0.47 & 0.40 & 0.41 & 0.53 & 0.46 \\
\hline \multirow{2}{*}{ 分子屈折 $\left\{\begin{array}{l}\text { 計算 } \\
\text { 赑 }\end{array}\right.$} & 269 & 266 & 168 & 133 & 130 & 126 & 112 \\
\hline & 271.2 & 267.5 & 168.1 & 131.5 & 129.6 & 125.8 & 110.9 \\
\hline
\end{tabular}


第 5 表 水添パラフィン・ヘンゾール縮合油

水素添加條件

貝料

能媒量 \%

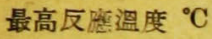

反瞣時間 分

$\mathrm{H}_{2}$ 初厥 atm

$\mathrm{H}_{2}$ 最高壓 $\mathrm{atm}$

$\mathrm{H}_{2}$ 経遮 $\mathbf{a t m}$

$\mathrm{H}_{2}$ 吸收量 $\%$ (重量 $\%$ )

水添緛合油性㹜

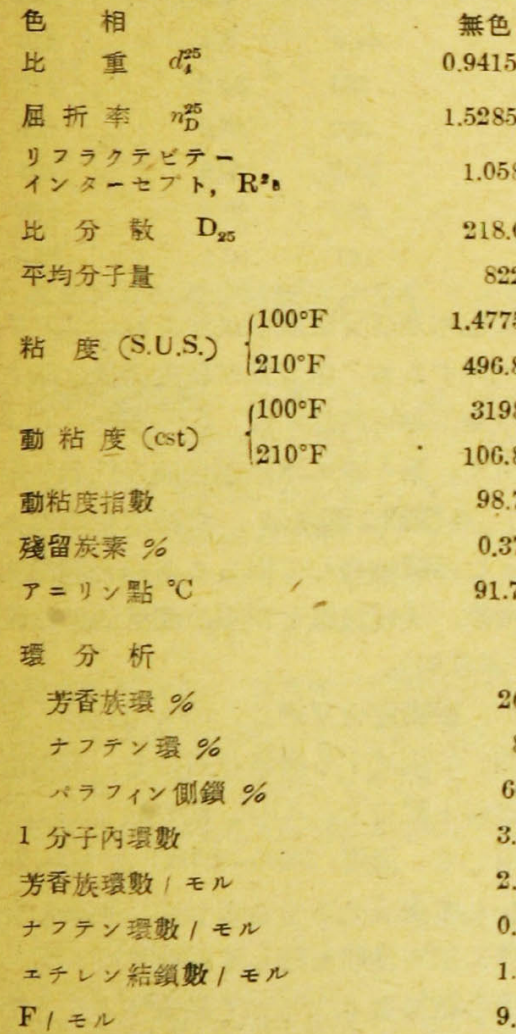

0.50

無色

5285

1.058

18.6

22

4775

8

198

0.37

1.7
B-3

180

120

60

72

11

0.88

98.7

26

8

66

3.5

2.7

0.8

1.0

9.1

葢慰 式 (推定)

分子式 (推定)

$\mathrm{C}_{n} \mathrm{H}_{2 n-23,2}$

$\mathrm{C}_{80.2} \mathrm{H}_{97.4}$
無色

0.9383

1.5255

1.056

218.6

812

1.4483

478.7

3136

102.9

97.2

0.37

97.1
B-5

3

150

120

60

73

29

0.55

無色

0.9031

1.5095

1.058

187.0

401

432.0

62.0

93.5

10.8

108.3

0.09

81.0

19

8

73

1.4

1.0

0.4

0.5

3.5
B-6

7

150

780

$50 \sim 70$

$15 \sim 47$

3.5

無色

0.8788

1.4865

1.037

157.1

390

306.8

56.1

.66 .4

9.1

119.8

0.06

110

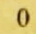

28

72

1.4

0

1.4

0.4

0.4

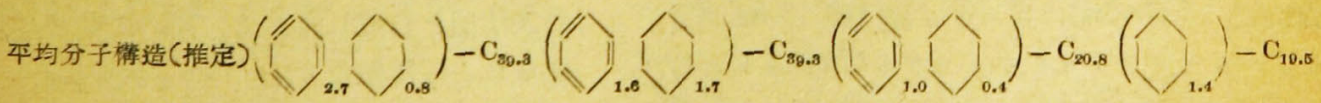
成渨 $\mathrm{C}$ 數/側顉 C數 0.534 比屈折

0.3273 0.504 0.404 0.431 分子屈折 $\left\{\begin{array}{l}\text { 贯測 } \\ \text { 計算 }\end{array}\right.$

269

0.3268

265

0.3308

133

0.3269

128

271.8

267.7

133.4

128,6 


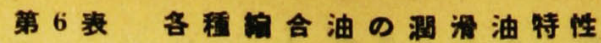

\begin{tabular}{|c|c|c|c|c|c|c|}
\hline \multirow[t]{2}{*}{ 油 } & \multirow[t]{2}{*}{ 㴼合炭化水案 } & \multirow[t]{2}{*}{ 色相 } & \multirow{2}{*}{$\begin{array}{c}\text { 殘留炭来 } \\
\%\end{array}$} & \multicolumn{2}{|c|}{ 動粘度 est } & \multirow{2}{*}{$\begin{array}{c}\text { 動粘度指數 } \\
\text { KVI }\end{array}$} \\
\hline & & & & $100^{\circ} \mathrm{F}$ & $210^{\circ} \mathrm{F}$ & \\
\hline B-43 & ペンソール & 淡贵 & 0.62 & 2872 & 98.8 & $\quad 99.5$ \\
\hline $\mathrm{T}-43$ & $ト ル オ ー r ~$ & 炏药 & 6.62 & 26,14 & 71.0 & 74.0 \\
\hline$X-43$ & $\neq 2 \square-n$ & 漠綠 & 0.76 & 3180 & 60.0 & 27.4 \\
\hline $\mathrm{TT}-43$ & テトラリン & 橙莏 & 0.71 & 7392 & 121 & 63.7 \\
\hline TT-44 & テトラリン & 橙鿒 & 1.19 & 2403 & 53.8 & 38.1 \\
\hline TT-45 & テトラリン & 橙兴 & 1.26 & 24717 & 216 & 47.5 \\
\hline $\mathrm{N}-43$ & ナフタリン & 絩黑 & - & 551 & 54.0 & 127 \\
\hline I -43 & インォタタン & 綠赤 & 0.59 & 33.3 & 6.0 & 137 \\
\hline$C-43$ & セタン & 繖赤 & 0.48 & 40.1 & 6.9 & 137 \\
\hline $\mathrm{CH}-43$ & チクローキ甘ン & 線黑 & 1.78 & 67.4 & 8.9 & 11.4 \\
\hline$D-43$ & デカリン & 紗壆 & 2.35 & 64,0 & 8.4 & 116 \\
\hline $\mathrm{N}_{\mathbf{a}}-43$ & ナフサ(混合基) & 綵黑 & 3.47 & 355 & 30.2 & 117 \\
\hline $\mathrm{Di}-43$ & 䡮油(混合烲) & 胃 & 2.52 & 553 & 35.6 & 105 \\
\hline - & ペタトン( $\left(\begin{array}{l}\text { イソブチレン } \\
\text { 直合䯏 }\end{array}\right)$ & 綠萌 & - & 7332 & 518 & 130 \\
\hline - & バ フフィン基性洞滑油 & 線尔 & 一 & 320 & 22.4 & 106 \\
\hline- & ナフテン其性洞滑油 & 絿赤 & - & 181 & 10.4 & -82.3 \\
\hline
\end{tabular}

一活性白土 (1: 1) 解媒 $32 \sim 160 \mathrm{~g}$ 之共に $2 l$ のフラ スコに採取し，之を㩇抖しつつ徐々に $400 \mathrm{~g}$ の監 素化石蠟を混和す。次に, 油浴中に於てフラスコ 溫度を一定の割合に上昇して, $180^{\circ} \mathrm{C}$ に至りて $1 \mathrm{hr}$ 保持して縮合反應を完結す。全反應を常壓下に行 ひ，溫度の上昇とともに溜出する未反應ベンゾー 几を凝缩して包收す。生成縮合油は $5 \mathrm{mmHg}$ 減壓 下に $150^{\circ} \mathrm{C}$ 迄拔頭して除去し, 白土精製す。

第 4 表に触媒望を變化して縮合琠驗せる結果を 收錄す。

第 8 圖に, 樎合用触媒 ( $\mathrm{AlCI}$ ) 量の變化に件 ぶ.縮合油性狀の變化を示す。此の國より明白なる

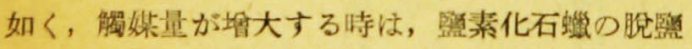
素重合とは反對に，解重合促進せられ，生成する 縮合油の比重, 届折率, 粘度, 平均分子量等が低 下す。然れども，触媒量の變化に依て縮合油の芳 香族性は變化なく，ヘンタールの縮合量\%及び芳

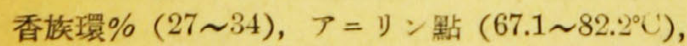
リフラクテピテーインターセプト (1.063〜1.064), 比分散（-234.3〜240.9）は略々一定なり。

パラフィンペンゾール縮合油を低溫壓水添する 際にはその主成分なる多環式アルキ几芳香族炭化 水素は多環式アルキルナフテン炭化水素に變化し
同時に色相及び安定度改良せられ，アニリン點著 しく上昇するも，粘度及び粘度指數は殆ど變化せ 才。水素添加用觸媒には $\mathrm{Ni}$-碃藻土 $(1.0: 1.5)$ を使用す。第 5 表に水添縮合油の性狀を示す。

（2）各種縮合潤滑油各種炭化水素々監素化 石婐とを接触縮合して得らるる縮合潤滑油の粘度 粘度指数，殘留炭素を市販の潤滑油に比較表示す （第 6 表参照）。

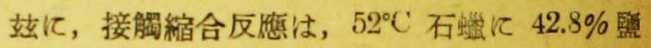
素添加して生成する監素化石蠟を, 等容積の炭化 水素資料上混合L, $\mathrm{AICl}$-活性白土 $(1: 1) 5 \sim 9 \%$ を使用して, 溫度 $180^{\circ} \sim 220^{\circ} \mathrm{C}$ 亿 $60 \sim 240$ 分接 解縮合して生成せるものにして, 生成縮合油は縮 合條件に依て性狀を著しく變化す。

以上の結果より次の如く結論することを得。

（1）監素化石蠟とアルキル芳香族及び水素化芳 香族炭化水素々の接觸縮合几依て, 極めて高粘度 の潤滑油を合成し得るも，同時に粘度指數を向上 することは困難なり。

(2) 監素化石蠟とナフタリン及びベンゾールと を接觸縮合することに依て，比较的容易に高粘度 指数の潤滑油を合成し得。生成する縮合油の粘度 は，縮合溫度，觸媒量等を變化することに依て， 
任意て變化するとこを得。

(3) 縮合潤滑油は, 又, ナフテン炭化水素之監 素化石蠟とを接触縮合して合成し得。此の際生成 する縮合油は，粘度並に粘度指數ともに高きも， 殘留炭素多〈, 安定度比較的低し。

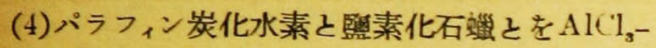
活性白土を觸媒として接䚡縮合する祭には，パラ フィン炭化水素は稀釋劑として㗢き, 低粘度の脫 檻素重合油を生成す。その粘度指數極めて高く, 稀秷劑なしに合成せる瞈監素重合油よりる安定度 高し。

(5) 鑛油つナフサ溜分及び輕油溜分上䕄素化石
蠟亡を接觸縮合する際には，芳香族及びナフテン 炭化水素は縮合作用に與り，パラフィン炭化水素は 稀釋劑として働き，高粘度指數の潤滑油を合成す。 但し, 此の縮合油注安定度比較的低し。 (2604.

\section{17) (東京工業大學助数授)}

\section{(客都交献)}

（1）田中, 小林, 古筫，小野口，原，燃協誌， 20, 昭16, 1031；22, 炤18,516, 535

(2) 田中, 小林, 古本, 工化誌, 36 , 昭8; 田中, 小 林, 降旗, 工化誌, 39, 昭 11,115 ; 田中, 小林, 工化 誌, 39, 炤11，413; 田中, 小林, 西, 工化誌, 37 , 昭 9 , 480 ; 田中, 小林, 日就誌, 1 , 昭 9,177 。

（3）阿部，松本，森川，燃協誌， 21，昭 17,663

\section{(15頁より)}

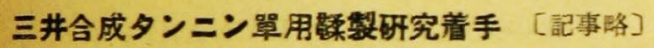
(荤經 4 月 30 日)

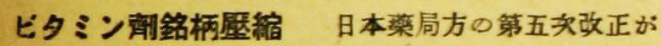

斯行せられビタミン敖の局方外製造中止（ 3 月間は製

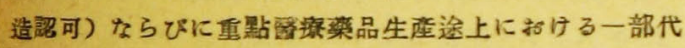

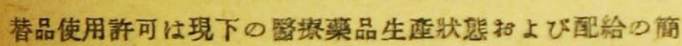
菜化に重要な役割を果す的のとして業界に多大の反筷を 呼んてるる。[以下略](连經 4 月 7 日)

日本藥局方一部改正厚生省ては決践段階に對處 して圂民登療の確保勤知力の保持坦强軍霖充足及び防空

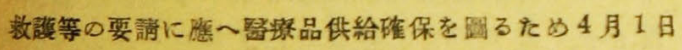
を期し日本藥局方の一部改正を行つた今包改正の要旨は 左の通りである

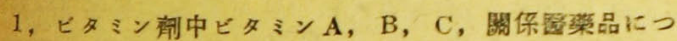
き規格を定めその品面の統一を圖り慜局方品以外の \& のは製造させるとととしれ，例へばどタミンAの場合 $\kappa$ 干單位红肝油, 1 萬單位注强肝油, 3 萬 3 干單位任 ヒタミンA油と名稱と規格を統一した, 從來のるのの

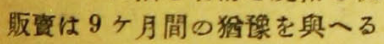

2 ，注射垶つ棁定を設け且つ注射用として頻繁に用ひら れる嘿化カルンウム及び睵萄糖につき所要の改正を加 一供給の算加を圆つた

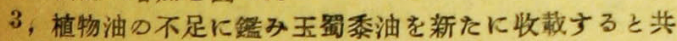

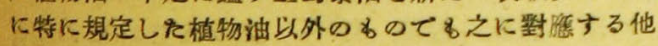
○植物油を使用し得る途を拓いた

4, 倵形菜として需要の多い各種澱粉の不足を補ふため

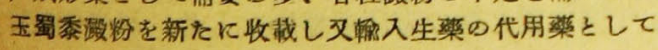

快明菜及び延命草を新たに加へた

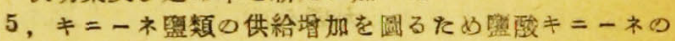
代りに硫酸キニーネを用ふることとしその規格に所要 の改正を加へた

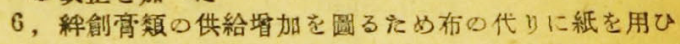
得ることとした

7, クロラミンの不足を補ふためクロラミン B及びク口 ラミンXを加一葡萄䊒の不足さ補ふため舆精を新たに 收裁した

8, 黄色ワセリンの代用としてパラフイン軟㛙を新たに 收載し业色ワセリン含有製劑中その代りにバフイン 軟弯を用ひ得るとととした

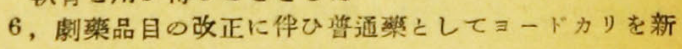
たに收战した

10, アセタルソール外 41 品につきその容器不足に选み 眝䒺法の規定を悢和した

11, 試带としてメク惨酸外 13 品を新たに收栈した

12, カ》䜤源の不足に鎦み定規液として2分定規ナト口 ン波及び 10 分定規ナトロン液を新たに收裁し 2 分定 規カり㳸及び10分定规カリ液に代り滴定に优用し得る とととしたること

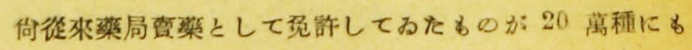
及んてるたが今回てれを左の 45 矰目に限定するてとれ したので, 今後は整藥品め名稱す規格統一し何處でど

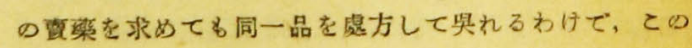
面格名近く決定する

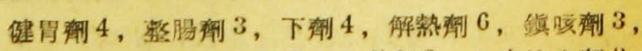

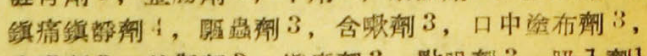

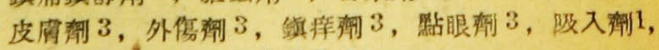
洗眼剂 $1, "$ (日社經 4 月 5 日)

(以下30頁下段一続く) 